\title{
Phenotypic virulence analysis of Pyricularia grisea isolates from Brazilian upland rice cultivars ${ }^{(1)}$
}

\author{
Marta Cristina Filippi ${ }^{(2)}$ and Anne Sitarama Prabhu ${ }^{(2)}$
}

\begin{abstract}
Phenotypic virulence analysis was made on population of Pyricularia grisea isolates collected from 10 upland cultivars in three distinct rice breeding sites, with the objective of studying the degree of similarity in the phenotypic virulence among the isolates, the composition of races, and their virulence pattern. Sixteen races were identified based on the reaction type on eight standard international differentials, the predominant ones being IB-9 and IB-41. The virulence frequency was high on IAC 47 and IAC 165 among medium and early maturing cultivars, respectively. The frequency of isolates virulent was greater on upland rice cultivars $(51.1 \%)$ than on irrigated rice cultivars $(21.8 \%)$. Both virulent and avirulent isolates were present in the population of $P$. grisea to the known genes in the near isogenic lines. Of 72 test isolates, $94.4 \%$ were virulent for genes $\mathrm{Pi}-3$ and Pi-4a. The virulence frequencies were relatively lower in decreasing order on Pi-1, Pi-4b and Pi-2. The coefficient of similarity ranged from 0.28 to 1.0 among the isolates pertaining to different races, while within the race IB-9, it varied from 0.56 to 1.0 . Considering the coefficient of similarity of $0.81,72 \%$ of isolates of race IB- 9 exhibited similar pattern of virulence.
\end{abstract}

Index terms: pathotype, Oryza sativa, Magnaporthe grisea, physiologic races, pathogenicity.

\section{Análise fenotípica da virulência dos isolados de Pyricularia grisea, coletados em cultivares de arroz de terras altas}

\begin{abstract}
Resumo - Foi conduzido um estudo de virulência fenotípica da população de Pyricularia grisea, coletada de 10 cultivares de arroz de terras altas, em três locais distintos, objetivando determinar o grau de similaridade entre virulência fenotípica de isolados, a composição de raças fisiológicas e seu padrão de virulência nas cultivares de arroz. Identificaram-se 16 raças, com base no tipo de reação nas oito diferenciadoras internacionais, das quais IB-9 e IB- 41 foram as predominantes. A freqüência de virulência foi alta nas cultivares IAC 47 e IAC 165 entre as de ciclo médio e precoce, respectivamente. A frequiência dos isolados virulentos nas cultivares de terras altas foi maior $(51,1 \%)$ do que nas cultivares irrigadas $(21,8 \%)$. Ambos os isolados virulentos e avirulentos às linhas isogênicas estavam presentes na população de $P$. grisea testada. Dos 72 isolados estudados, $94,4 \%$ foram virulentos aos genes Pi-3 e Pi-4a. A frequiência de virulência foi relativamente baixa, em ordem decrescente, em Pi-1, Pi-4b e Pi-2. O coeficiente de similaridade variou de 0,28 a 1,0 entre as diferentes raças dos isolados. O coeficiente de similaridade entre os isolados pertencentes ao grupo IB- 9 variou de 0,56 a 1,0. Considerando o coeficiente de similaridade de $0,81,72 \%$ dos isolados IB-9 apresentaram o mesmo padrão de virulência.
\end{abstract}

Termos para indexação: patótipo, Oryza sativa, Magnaporthe grisea, raça fisiológica, patogenicidade.

\section{Introduction}

The rice blast pathogen Pyricularia grisea (Cooke) Sacc. is a complex species and composed of

\footnotetext{
(1)Accepted for publication on January 27, 2000.

(2)Embrapa-Centro Nacional de Pesquisa de Arroz e Feijão (CNPAF), Caixa Postal 179, CEP 75375-000 Santo Antônio de Goiás, GO. E-mail:cristina@cnpaf.embrapa.br, prabhu@cnpaf.embrapa.br
}

groups of isolates that are diverse in phenotypic virulence. Collection and testing of pathogen populations are vital for any study leading to determine the basis of host plant resistance and virulence diversity. Any change in the frequency of virulence will change the effectiveness of a certain variety as demonstrated by the breakdown of resistance in many cultivars (Kiyosawa, 1982). The average life span of many resistant rice cultivars is 2 to 3 years (Leung et al., 1988). Varietal resistance 
breakdown is commonly attributed to new races or increased population of matching races with time, narrow spectrum of cultivar resistance, amount of pathogen around the field, area cultivated, mutation frequency of avirulence to virulence, amount of virulence strains at the time of release, multiplication rate of virulent strains (Kiyosawa, 1982) in addition to the failure of breeding lines to encounter low frequency compatible pathotypes in a population (Correa-Victoria \& Zeigler, 1993).

Several races of the blast fungus $P$. grisea have been reported in different parts of the world. As many as 250 races have been reported to occur in the Philippines (Ou, 1980). Forty five races of $P$. grisea representing all nine race groups were identified in Santa Rosa rice breeding station in Colombia (CorreaVictoria \& Zeigler, 1993). At the same location, Levy et al. (1993) identified 39 races in a collection of 151 isolates of $P$. grisea from 15 rice cultivars. In Brazil, the occurrence of physiologic races have also been reported in different predominantly rice growing States (Ribeiro \& Terres, 1987; Filippi \& Prabhu, 1996). Also, pathogenic variation has been demonstrated in populations derived from single spore isolates originated from a single lesion suggesting high pathogenic instability (Giatgong \& Frederiksen, 1969; Bedendo et al., 1979; Ou, 1980; Valent \& Chumley, 1991). On the other hand, Bonman et al. (1986) consider that isolates of P. grisea are pathogenically stable.

Recent studies with avirulence genes have shown that the instability of some isolates occur during recombination between repetitive sequences present in the fungus genome confirming the earlier reports of high pathogenic instability in some isolates (Valent \& Chumley, 1991).

However, the MGR-DNA fingerprinting methods have shown that $P$. grisea isolates pathogenic to rice can be grouped into genetically distinct lineages (Levy et al., 1991; Correa-Victoria et al., 1994). Even though a simple relationship between lineage and pathotypes was originally postulated (Levy et al., 1991), later studies showed diversity for virulence within lineages on many cultivars (Xia et al., 1993; Correa-Victoria et al., 1994; Zeigler et al., 1995). According to Leong et al. (1994), DNA fingerprinting cannot always be used reliably to determine pathotypes of the fungus. The knowledge on phenotypic virulence analysis of the isolates, obtained from upland rice cultivars in different experimental stations, greatly facilitates incorporation of resistance genes in the cultivars well adapted to local conditions. The availability of five near isogenic lines of cultivar CO 39 (MacKill \& Bonman, 1992), each one carrying a known resistance gene allows the determination of absolute virulence spectrum of pathotypes, although limited to few genes. The most practical approach for characterizing the pathogen population of $P$. grisea, in the country, in relation to virulence structures is the utilization of commercial cultivars as local differentials, in addition to those ones with known resistance genes.

The objective of the present investigation was to determine the degree of similarity in the phenotypic virulence among the isolates obtained from upland rice cultivars, the composition of races and their virulence pattern on rice cultivars.

\section{Material e Methods}

\section{Isolates}

Isolates of $P$. grisea were collected from 10 upland rice cultivars (Araguaia, Carajás, Centro América, Cuiabana, Guarani, IAC 47, IAC 165, Rio Paranaíba, Rio Paraguai and Tangará) from field trials in the experimental stations of Embrapa-Centro Nacional de Pesquisa de Arroz e Feijão, Santo Antônio de Goiás, GO; Jaciara, MT, and Vilhena, RO, Brazil, over a period of three years. Single conidial isolates were established from sporulating lesions and stock cultivars were maintained on filter paper disks in sterilized butter paper bags at $4^{\circ} \mathrm{C} \pm 1^{\circ} \mathrm{C}$ in the refrigerator. More than 200 isolates were examined for their sporulating ability and from them, 72 were selected for evaluation.

\section{Test plant material}

Twenty-four rice genotypes including eight from upland (Caiapó, IAC 47, IAC 165, IAC 25, Rio Paranaíba, Guarani, Cuiabana, Araguaia) and six from irrigated (Cica 8, Cica 9, Oryzica Lhaños-5, Aliança, Metica, BR-IRGA 409) rice cultivars, five near isogenic lines (C101LAC, C101A51, C104PKT, C101PKT, C105TTP4L23) of CO-39 (NIL's) and five standard checks (Fukunishiki, Fujisaka, IRAT-13, BL-1, Ceysvoni) were used for evaluating the virulence of 72 selected isolates. The selection of the test material was based on differential reactions to pathotypes obtained in earlier studies (Correa- 
Victoria \& Zeigler, 1993). The commercial rice cultivars and some genotypes possess unknown resistance genes whereas in NIL's blast resistance was conferred by known independent dominant genes. The virulence frequencies were based on eight upland rice cultivars and six irrigated rice cultivars. The virulence pattern of the isolates from upland rice cultivars was also determined on five NIL's with known resistance genes. Race identification was made using the eight standard international differentials (Atkins et al., 1967).

The test material was planted in plastic trays $(15 \mathrm{x}$ $30 \mathrm{~cm}$ ) containing $3 \mathrm{~kg}$ of soil fertilized with NPK (5 g of $5-30-15+\mathrm{Zn}, 3 \mathrm{~g}$ of ammonium sulfate per $3 \mathrm{~kg}$ of soil). The genotypes totaling 32 were sown ( 10 to 12 seeds) in $5 \mathrm{~cm}$ rows in two trays, sixteen in one tray and other 16 , including eight international differentials, in another tray.

\section{Inoculation procedure}

For sporulation the isolates were grown on oatmeal agar in Petri dishes and incubated at $25^{\circ} \mathrm{C}$ for seven days. Inoculum was prepared as described earlier (Prabhu et al., 1992) and concentration was adjusted to $3 \times 10^{5}$ conidia per mL. Twenty-two day old plants, with three fully expanded leaves, were inoculated by spraying with aqueous spore suspension on the leaves, until run-off, using an atomizer connected to an air compressor. Inoculated plants were incubated in moist chamber for 24 hours at 20 to $24^{\circ} \mathrm{C}$ after which they were kept in the greenhouse at temperatures ranging from 25 to $28^{\circ} \mathrm{C}$.

\section{Disease assessment and analysis}

The disease reaction was assessed nine days after inoculation following the visual rating scale varying from 0 to 9 . The isolates that induced typical sporulating lesions were considered virulent or compatible (4-9) and necrotic nonsporulating lesions as incompatible (0-3). Inoculation tests were repeated twice and the ones that gave consistent and uniform reaction were utilized for analysis.

The virulence pattern was analyzed based on the similarity of reaction type among isolates. A binary matrix indicating compatible reaction (1) and incompatible reaction ( 0 ) of each isolate was utilized for constructing a matrix of similarity between all pairs of isolate according to the coefficient of Dice (1945):

$\mathrm{GS}=2 \mathrm{~N}_{\mathrm{xy}} /\left(\mathrm{N}_{\mathrm{x}}+\mathrm{N}_{\mathrm{y}}\right)$

where,

GS is the similarity coefficient between isolates $\mathrm{x}$ and $\mathrm{y}$; $\mathrm{N}_{\mathrm{xy}}$, number of compatible or incompatible reactions of two isolates $\mathrm{x}$ and $\mathrm{y}$;

$N_{x}+N_{y}$, total number of observed reactions for that pair of isolates. GS value of 1 indicates identity of two isolates, while GS value of 0 indicates maximum diversity.

The phenogram of the isolates was constructed based on the matrix similarity using unweighted pair groups with arithmetical averages by (UPGMA) SAHN (sequential agglomerative hierarchical and nested method) program of the NTSYS-pc version 1-I (Numerical taxonomy and multivariate analysis system) according to Rohlf (1989). A similarity level of 0.8 was used to group the isolates.

\section{Results and Discussion}

Sixteen races were identified based on the reaction type of eight standard international differentials in a sample population of $P$. grisea collected mainly from three test sites under upland conditions (Figure 1). They represented only three international race groups IB, IA and IC, the most predominant races being IB-9 and IB-41 as reported in previous studies (Prabhu et al., 1992). While $82 \%$ of the isolates belonged to the race group IB, only $12 \%$ and $4 \%$ represented IA and IC. The single race representatives were IB-1, IB-2, IB-5, IB-9, IB-10, IB-13, IB-14, IB-25, IA-9 and IC-1 indicating the low frequency of their occurrence.

The international differential Raminad Str. 3 utilized in the race identification of races in Brazil and Colombia was genetically different. In another study, Raminad Str. 3 from Colombia showed a high degree of susceptibility to all races belonging to IB-9 group, whereas Raminad Str. 3 of Brazil was highly resistant. If Raminad Str. 3 from Brazil were to be included in tests conducted in Colombia, 91 of the 131 isolates

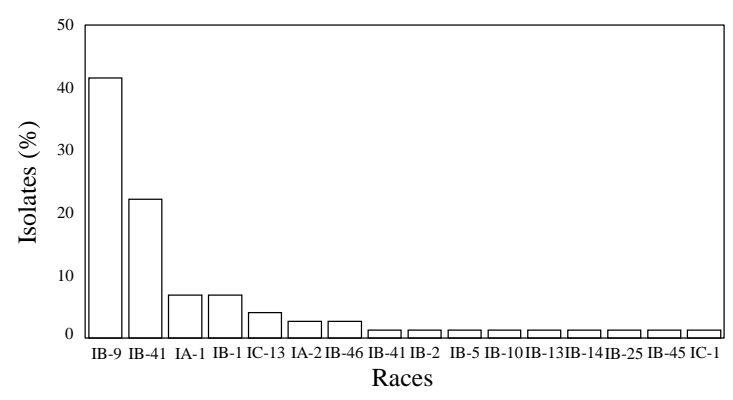

Figure 1. Race frequency of isolates of Pyricularia grisea obtained from commercial upland rice cultivars. 
reported to belong to IA group (CorreaVictoria \& Zeigler, 1993) would pertain to IB group. These results suggest the necessity of utilizing differentials with the same accession number and source to compare test results. The total number of races in the population analyzed did not represent all race groups whereas in Colombia 45 races representing all groups were obtained among isolates retrieved from 15 rice cultivars. The major difference in Brazilian and Colombian pathogen population was $47 \%$ of the isolates belonging to seven most common races in Colombia were avirulent to Zenith in contrast to the 5\% avirulent isolates in Brazil.

The most predominant race IB- 9 has been recovered from all 10 rice cultivars including the improved ones such as Carajás and Rio Paranaíba. The recovery frequencies were higher from traditional susceptible cultivars IAC 47 and IAC 165. A relatively high frequency of race IB-41 was obtained from the improved rice cultivar Centro America. The races, which were not very frequent, were recovered at random from different cultivars.

Distinct differences in virulence pattern were observed in six upland and eight irrigated rice cultivars (Figure 2). Among the medium maturing cultivars, the matching virulences in the population was higher in decreasing order on IAC 47, Rio Paranaíba, Cuiabana, Caiapó and Araguaia whereas in early maturing cultivars the mean virulence frequency was highest on IAC 165, followed by IAC 25 and Guarani (Figure 2). The high mean virulence frequency on IAC 47 and IAC 165 explains the high degree of susceptibility of these cultivars as compared to other test cultivars under field conditions. The low frequency of virulence on Araguaia indicates moderate susceptibility of the cultivar in field tests. The frequency of isolates virulent on eight upland rice cultivars was $51.1 \%$ and on irrigated rice cultivars $21.8 \%$. However, the high frequency of $95.8 \%$ on Metica-1 indicates the pre-existence of virulences for irrigated commercial rice cultivars in the populations of $P$. grisea retrieved from upland rice cultivars. None of the isolates were virulent on Cica-8, Cica-9, Oryzica L-5, and these results are in accord with those obtained in studies conducted at Cali, Colombia (CorreaVictoria \& Zeigler, 1993).

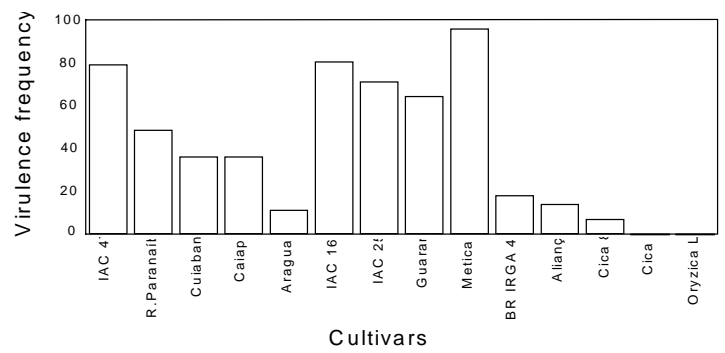

Figure 2. Virulence pattern of 72 Pyricularia grisea isolates on upland and irrigated rice cultivars (upland rice cultivars medium duration: IAC 47, R. Paranaíba, Cuiabana, Caiapó, Araguaia; short duration: IAC 165, IAC 25, Guarani; irrigated rice cultivars: Metica 1, BR IRGA 409, Aliança, Cica 8, Cica 9, Oryzica L.5).

In samples collected from three upland rice sites, both virulent and avirulent isolates were detected in the population of $P$. grisea to the known genes in NIL's. Of 72 isolates, $94.4 \%$ were virulent for genes Pi-3 and Pi-4a, which were derived from the same donor Pai-Kan-Tao (Table 1). These genes have never been utilized in upland or irrigated rice breeding and also none of the cultivars from where the isolate was retrieved had these genes. However, the data have shown that the virulence on $\mathrm{Pi}-3$ and $\mathrm{Pi}-4$ pre-existed abundantly in populations of $P$. grisea. The fitness of virulences on these genes to survive even when it was unnecessary shows the quality of the genes. The virulence frequencies were relatively lower in descending order on $\mathrm{Pi}-1, \mathrm{Pi}-4 \mathrm{~b}$ and $\mathrm{Pi}-2$. The recurrent parent CO-39 may also possess a major resistance gene because $4 \%$ of the isolates were avirulent. The virulence in upland rice $P$. grisea population is not related to collection sites because similar ranking of the virulence frequencies of isolates was observed on NIL's. The data in Table 1 show that the host from which they were collected conditions the virulence pattern. The frequency of isolates retrieved from Cuiabana virulent to $\mathrm{Pi}-1$ and $\mathrm{Pi}-2$ were $83.3 \%$ and $16.7 \%$, respectively. On the other hand, the order was reverse for the isolates originated from Rio Paranaíba being 14.3\% for Pi-1 and 57.1\% for Pi-2. In general, the virulences were low for the gene Pi-2. These results show the necessity for further studies on virulence pattern in extensive 
Table 1. The percentage of isolates of Pyricularia grisea, from six upland rice cultivars in Brazil, virulent to the known resistance genes in near isogenic lines (NIL's) of CO-39.

\begin{tabular}{lcrrrrrrr}
\hline \multirow{2}{*}{ NIL's } & $\begin{array}{c}\text { Resistance } \\
\text { genes }\end{array}$ & \multicolumn{7}{c}{ Isolates $(\%)$} \\
\cline { 2 - 8 } & & IAC 47 & R. Paranaíba & Cuiabana & IAC 165 & Guarani & C. América & Total \\
\hline C101LAC $^{(1)}$ & Pi-1 & 25.00 & 14.29 & 83.34 & 30.00 & 50.00 & 66.67 & 44.9 \\
C101A51 $^{(1)}$ & Pi-2 & 8.34 & 57.14 & 16.67 & 20.00 & 31.25 & 10.00 & 23.9 \\
C104PKT $^{(1)}$ & Pi-3 & 83.34 & 100.00 & 83.34 & 100.00 & 100.00 & 100.00 & 94.4 \\
C101PKT $^{(1)}$ & Pi-4a & 83.34 & 100.00 & 83.34 & 100.00 & 100.00 & 100.00 & 94.4 \\
C105TTP $^{(1)}$ & Pi-4b & 41.67 & 28.57 & 16.67 & 50.00 & 50.00 & 40.00 & 37.8 \\
CO-39 $^{(2)}$ & & 83.34 & 100.00 & 100.00 & 100.00 & 93.75 & 100.00 & 96.2 \\
\hline
\end{tabular}

${ }^{(1)}$ Near isogenic lines. ${ }^{(2)}$ Recurrent parent.

cultivated areas without the interference caused by population from other cultivars in the experimental fields. Changes in virulence pattern of blast races can be monitored using the NIL's. The virulence spectrum of isolates on C101A51 carrying the gene from donor parent 5173 is very low, in addition to exhibiting, in general, a type 4 reaction. The intermediate reaction is possibly controlled by genes other than the resistance gene $\mathrm{Pi}-2$ (MacKill \& Bonman, 1992). The isogenic line C101A51 seldom shows susceptibility under field conditions at Goiânia, and even the isolates virulent were weakly aggressive in controlled inoculation tests. The gene Pi-2 can be usefully utilized in upland rice cultivars to exclude a great portion of pathogen population. But, when cultivars with $\mathrm{Pi}-2$ will be introduced and widely grown, virulence may become abundant as an adaptation to the resistance.

The coefficient of similarity varied from 0.28 to 1.00 among 72 isolates belonging to different races (Figure 3). In general, the grouping of isolates in the phenogram is unrelated to the origin of isolates. The little diversity in the pathogen population can be explained by the collection of isolates from the cultivars with narrow genetic basis and from interplot interference in the collection sites.

The similarity coefficients between pairs of isolates belonging to race IB- 9 are shown in Table 2 . The coefficients within the race IB-9 ranged from 0.56 to 1.0 . High similarity coefficients over 0.91 were obtained between isolates: No 1 and 21, 23, 25, 68; and pairs of isolates 2 and 14; 9 and 14; 16 and 21; 16 and $25 ; 21$ and $23 ; 21$ and $68 ; 23$ and $25 ; 23$ and $68 ; 23$ and 85 . The isolates 61 and 81 collected from panicle and leaf lesions of IAC 165 planted in experimental stations at Vilhena and Jaciara, respectively, were dissimilar (0.65) to majority of the isolates of the race IB-9.

Considering the coefficient of similarity of 0.81 , $72 \%$ of the isolates of race IB- 9 were similar in virulence exhibiting differences in compatibility on two or three of the 24 test cultivars. The similarity coefficients were not based on the source of the isolate or collection site. However, the isolates 23 and 16 from leaf and panicle, respectively, of the cultivar Rio Paranaíba showed similarity coefficient 1.0. Results indicated that the pattern of virulence of the isolates of predominant race maintain certain degree of similarity as in the case of lineages.

Virulence gene fluctuations must be monitored constantly to adapt counter measures against directed selections of the pathogen. Specific genes for resistance to specific races are necessary to incorporate resistance in the commercial upland rice cultivars well adapted to Brazilian conditions. Backcrossing such genes into the recurrent parent is a practical means of improving widely grown susceptible cultivars. The resistance genes $\mathrm{Pi}-3$ and $\mathrm{Pi}-4 \mathrm{a}$ are not useful because of abundant preexisting virulence in the field population of $P$. grisea. Virulence in the field also exists for other genes but in low frequencies. Results obtained in the present 
Table 2. Similarity coefficients among the isolates pertaining to race IB-9 of Pyricularia grisea.

\begin{tabular}{|c|c|c|c|c|c|c|c|c|c|c|c|c|c|c|c|c|c|c|c|}
\hline Isolate $^{(1)}$ & 2 & 4 & 9 & 14 & 16 & 20 & 21 & 22 & 23 & 24 & 25 & 31 & 32 & 43 & 61 & 68 & 85 & 132 & 133 \\
\hline 1 & $0.81^{(2)}$ & 0.82 & 0.82 & 0.82 & 0.86 & 0.81 & 0.90 & 0.81 & 0.90 & 0.81 & 0.90 & 0.83 & 0.70 & 0.78 & 0.65 & 0.90 & 0.65 & 0.80 & 0.80 \\
\hline 2 & & 0.86 & 0.86 & 0.93 & 0.81 & 0.86 & 0.81 & 0.87 & 0.81 & 0.87 & 0.81 & 0.81 & 0.70 & 0.78 & 0.65 & 0.81 & 0.65 & 0.80 & 0.80 \\
\hline 4 & & & 0.85 & 0.85 & 0.81 & 0.85 & 0.83 & 0.85 & 0.81 & 0.85 & 0.81 & 0.81 & 0.70 & 0.78 & 0.65 & 0.81 & 0.65 & 0.80 & 0.80 \\
\hline 9 & & & & 0.92 & 0.81 & 0.86 & 0.81 & 0.87 & 0.81 & 0.87 & 0.81 & 0.81 & 0.70 & 0.78 & 0.81 & 0.81 & 0.65 & 0.80 & 0.80 \\
\hline 14 & & & & & 0.81 & 0.86 & 0.81 & 0.87 & 0.81 & 0.87 & 0.81 & 0.81 & 0.70 & 0.78 & 0.65 & 0.81 & 0.65 & 0.80 & 0.80 \\
\hline 16 & & & & & & 0.81 & 0.95 & 0.81 & 1.00 & 0.81 & 0.95 & 0.83 & 0.70 & 0.78 & 0.65 & 0.93 & 0.65 & 0.80 & 0.80 \\
\hline 20 & & & & & & & 0.81 & 0.86 & 0.81 & 0.86 & 0.81 & 0.81 & 0.70 & 0.78 & 0.65 & 0.81 & 0.65 & 0.80 & 0.80 \\
\hline 21 & & & & & & & & 0.81 & 0.95 & 0.81 & 1.00 & 0.83 & 0.70 & 0.78 & 0.65 & 0.93 & 0.65 & 0.80 & 0.80 \\
\hline 22 & & & & & & & & & 0.81 & 1.00 & 0.81 & 0.81 & 0.70 & 0.78 & 0.65 & 0.81 & 0.65 & 0.80 & 0.80 \\
\hline 23 & & & & & & & & & & 0.81 & 0.95 & 0.83 & 0.70 & 0.78 & 0.65 & 0.93 & 0.65 & 0.80 & 0.80 \\
\hline 24 & & & & & & & & & & & 0.81 & 0.83 & 0.70 & 0.78 & 0.65 & 0.81 & 0.65 & 0.80 & 0.80 \\
\hline 25 & & & & & & & & & & & & 0.83 & 0.70 & 0.78 & 0.65 & 0.93 & 0.65 & 0.80 & 0.80 \\
\hline 31 & & & & & & & & & & & & & 0.70 & 0.78 & 0.65 & 0.83 & 0.65 & 0.80 & 0.80 \\
\hline 32 & & & & & & & & & & & & & & 0.70 & 0.65 & 0.70 & 0.65 & 0.70 & 0.70 \\
\hline 43 & & & & & & & & & & & & & & & 0.65 & 0.78 & 0.65 & 0.70 & 0.70 \\
\hline 61 & & & & & & & & & & & & & & & & 0.65 & 0.72 & 0.65 & 0.65 \\
\hline 68 & & & & & & & & & & & & & & & & & 0.65 & 0.80 & 0.80 \\
\hline 85 & & & & & & & & & & & & & & & & & & 0.65 & 0.65 \\
\hline 132 & & & & & & & & & & & & & & & & & & & 0.87 \\
\hline
\end{tabular}




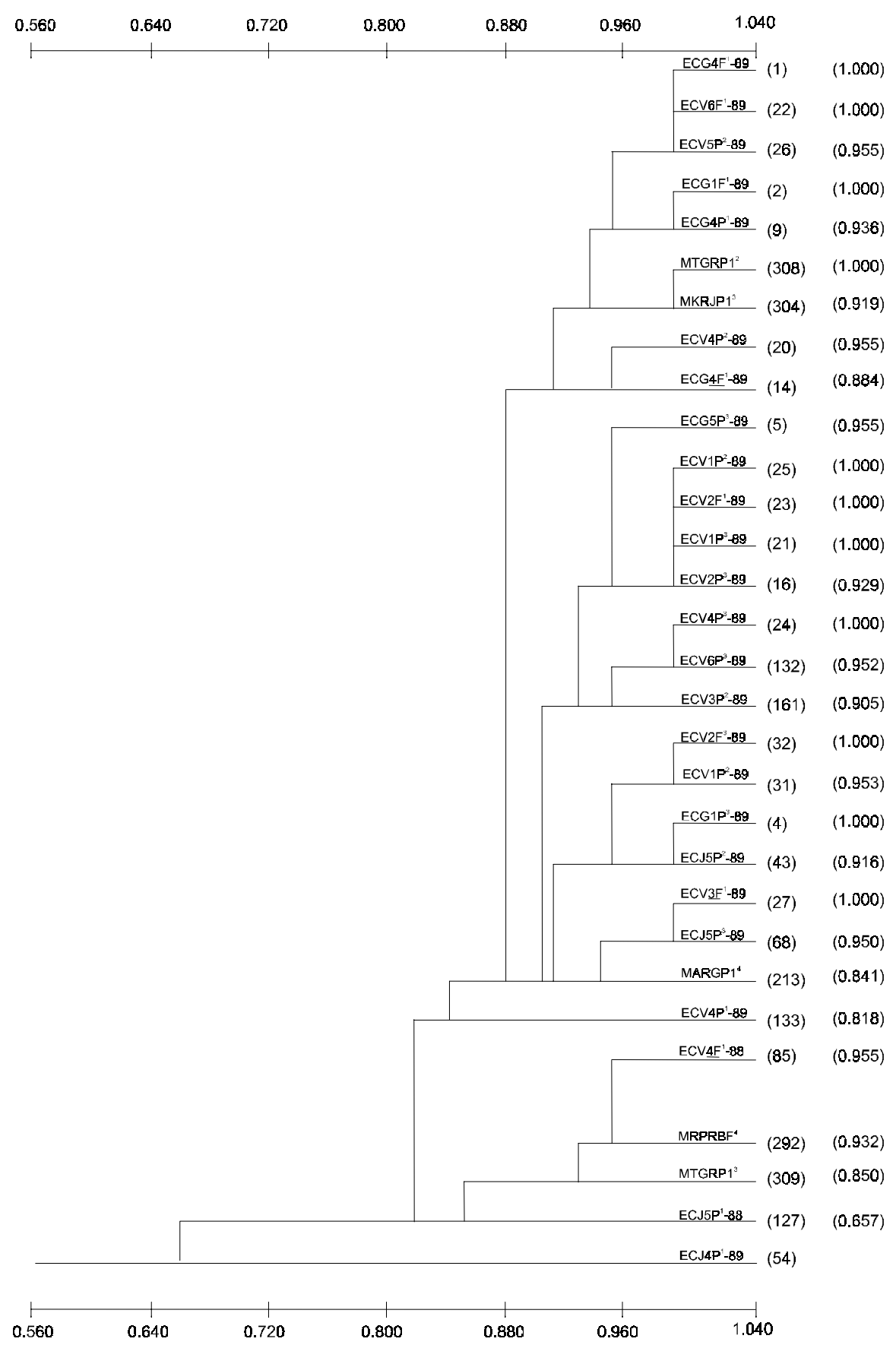

Figure 3. Dendogram of 30 isolates (race IB-9) of Pyricularia grisea, constructed using UPGMA, based on Dice's similarity coefficients. 
study do not indicate the adaptation of races to these genes but testify the fitness of the virulence to survive even in their absence in nature. Individual differences in phenotypic virulence is a fact and conclusions based on single or few isolates are misleading. The isolates in this study adequately represent the population and variations between individuals with differences in virulence within the population is inevitable. Further studies on characterization of $P$. grisea using RFLP and RAPD markers are important to compliment the virulence test results.

\section{Conclusions}

1. Sixteen races of Pyricularia grisea are identified in upland rice and the predominate ones are IB-9 and IB-41.

2. The isolates pertaining to race IB-9 exhibit similar virulence pattern.

3.The cultivars from which the isolates are collected condition the virulence, independent of the collection site.

\section{References}

ATKINS, J. C.; ROBERT, A. L.; ADAIR, C. R.; GOTO, K.; KOZOKA, T.; KANOGITA, R.; YAMADA, M.; MATSUMOTO, S. An international set of rice varieties for differentiating races of Pyricularia oryzae. Phytopathology, St. Paul, v. 57, p. 297-301, 1967.

BEDENDO, I. P.; RIBEIRO, A. S.; CARDOSO, C. N. Variabilidade do fungo de Pyricularia oryzae, agente causal da brusone no arroz. Summa Phytopathologica, Jaboticabal, v. 5, p. 106-109, 1979.

BONMAN, J. M.; VERGEL DE DIOS, T. I.; KHIN, M. M. Physiologic specialization of Pyricularia oryzae in the Philippines. Plant Disease, St. Paul, v. 70, p. $767-$ $769,1986$.

CORREA-VICTORIA, F. J.; ZEIGLER, R. S. Pathogenic variability in Pyricularia grisea at a rice blast "hot-spot" breeding site in Eastern Colombia. Plant Disease, St. Paul, v. 77, p. 1029-1035, 1993.

CORREA-VICTORIA, F. J.; ZEIGLER, R. S.; LEVY, M. Virulence characteristics of genetic families of Pyricularia grisea in Colombia. In: ZEIGLER, R. S.; LEONG, S. A.; TENG, P. S. (Ed.). Rice blast disease. Wallingford : CAB International, 1994. p. 211-230.
DICE, L. R. Measures of the amount of ecological association between species. Ecology, Washington, v. 26, p. 297-302, 1945.

FILIPPI, M. C.; PRABHU, A. S. Inheritance of blast resistance in rice to two Pyricularia grisea races IB-1 and IB-9. Brazilian Journal of Genetics, Ribeirão Preto, v. 19 , n. 4, p. 599-604, 1996.

GIATGONG, P.; FREDERIKSEN, R. A. Pathogenic variability and cytology of monoconidial subcultures of Pyricularia oryzae. Phytopathology, St. Paul, v. 59, n. 8, p. 1152-1157, 1969.

KIYOSAWA, S. Genetics and epidemiological modeling of breakdown of plant disease resistance. Annual Review of Phytopathology, Palo Alto, v. 20, p. 93-117, 1982.

LEONG, S. A.; FARMAN, M.; SMITH, J.; BUDDE, A.; TOSA, Y.; NITTA, N. Molecular genetic approach to the study of cultivar specificity in the rice blast fungus. In: ZEIGLER, R. S.; LEONG, S. A.; TENG, P. S. (Ed.). Rice blast disease. Wallingford : CAB International, 1994. p. $87-110$.

LEUNG, H.; BORROMEO, E. S.; BERNARDO, M. A.; NOTTEGHEM, J. L. Genetic analysis of virulence in the rice blast fungus Magnaporthea grisea. Genetics, Bethesda, v. 78 , n. 9 , p. $1227-1233,1988$.

LEVY, M.; CORREA, F. J.; ZEIGLER, R. S.; XU, S.; HAMER, J. E. Genetic diversity of the rice blast fungus in a disease nursery in Colombia. Phytopathology, St. Paul, v. 83, p. 1427-1433, 1993.

LEVY, M.; ROMÃO, J.; MARCHETTI, M. A.; HAMER, J. E. DNA fingerprinting with dispersed repeated sequence resolves pathotypic diversity in the rice blast fungus. Plant Cell, Rockville, v. 3, p. 95-102, 1991.

MacKILL, D. J.; BONMAN, J. M. Inheritance of blast resistance in near-isogenic lines of rice. Phytopathology, St. Paul, v. 82, p. 746-749, 1992.

OU, S. H. Pathogen variability and host resistance of the rice blast fungus, Pyricularia oryzae Cav. Annual Review of Phytopathology, Palo Alto, v. 18, p. 167-187, 1980.

PRABHU, A. S.; FILIPPI, M. C.; CASTRO, N. Pathogenic variation among isolates of Pyricularia oryzae affecting rice, wheat and grasses in Brazil. International Journal of Pest Management, London, v. 38, p. 367371, 1992.

RIBEIRO, A. S.; TERRES, A. L. S. Variabilidade do fungo Pyricularia oryzae e sua relação com cultivares resistentes à brusone. Fitopatologia Brasileira, Brasília, v. 12, p. 316-321, 1987. 
ROHLF, F. J. Numerical taxonomy system of multivariate statistical program. Stony Brook: The State University of New York at Stony Brook, 1989. Não paginado.

VALENT, B.; CHUMLEY, F. G. Molecular genetic analysis of the rice blast fungus Magnaporthea grisea. Annual Review of Phytopathology, Palo Alto, v. 29, p. 443-467, 1991.

XIA, J. Q.; CORRELL, J. C.; LEE, F. N.; MARCHETTI, M. A.; RHOADS, D. D. DNA fingerprinting to examine micrographic variation in the Magnaporthea grisea (Pyricularia grisea) population in two rice fields in Arkansas. Phytopathology, St. Paul, v. 83, p. 1029-1035, 1993.

ZEIGLER, R. S.; COUC, L. X.; SCOTT, R. P.; BERNARDO, M. A.; CHEN, D. H.; VALENT, B.; NELSON, R. J. The relationship between lineage and virulence in Pyricularia grisea in the Philippines. Genetics, Bethesda, v. 85, p. 443-451, 1995. 